For without this reverence we can scarcely be committed to the value of being; it is the secret of what Pasternak called "the talent for life." Tomlinson is certainly out of season to recall us to the life of the moment conceived as an end in itself; and yet it is just this unseasonableness that puts him in harmony with what is lasting in our relations with the world.

\title{
Charles Tomlinson
}

Three Bagatelles

THE N I G H T - T R A IN

\author{
composed \\ solely of carbon and soot-roses \\ freighted tight \\ with a million \\ miniscule statuettes \\ of La Notte (Night) \\ stumbles on \\ between unlit halts \\ till daylight begins \\ to bleed its jet \\ windows white, and the night- \\ train softly \\ discomposes, rose \\ on soot-rose, \\ to become-white \\ white white- \\ the snow-plough \\ that refuses to go.
}


A T S A N T' A N TIMO

Flanking the place,

a cypress

stretches itself, its surface

working as the wind

travels it in a continual

breathing, an underwater

floating of foliage

upwards, till

compact and wavering

it flexes a sinuous

tip that chases

its own shadow

to and fro

across the still

stone tower.

\title{
P O E M
}

\author{
space \\ window \\ that looks into itself \\ a facing \\ both and \\ every way \\ colon \\ between green apple: \\ and vase of green \\ invisible \\ bed and breath \\ ebb and air-flow \\ below an unflawed \\ iridescence \\ of spiderweb
}

